\title{
E-Beam Deposition of Scandia-Stabilized Zirconia (ScSZ) Thin Films Co-Doped with Al
}

\author{
Nursultan Kainbayev ${ }^{1,2, *(\mathbb{D})}$, Mantas Sriubas ${ }^{1} \mathbb{D}$, Kristina Bockute ${ }^{1}$, Darius Virbukas ${ }^{1}$ and \\ Giedrius Laukaitis ${ }^{1}$ \\ 1 Physics Department, Kaunas University of Technology, Studentu str. 50, LT-51368 Kaunas, Lithuania; \\ mantas.sriubas@ktu.lt (M.S.); kristina.bockute@ktu.lt (K.B.); darius.virbukas@ktu.lt (D.V.); \\ giedrius.laukaitis@ktu.lt (G.L.) \\ 2 Department of Thermal Physics and Technical Physics, Al-Farabi Kazakh National University, \\ 71 al-Farabi Ave., Almaty 050040, Kazakhstan \\ * Correspondence: nursultan.kainbayev@ktu.edu
}

Received: 17 August 2020; Accepted: 6 September 2020; Published: 9 September 2020

\begin{abstract}
Scandia alumina stabilized zirconia (ScAlSZ) thin films were deposited using e-beam evaporation, and the effects of deposition parameters on the structure and chemical composition were investigated. The analysis of thin films was carried out using Energy-dispersive X-ray spectroscopy (EDS), X-ray photoelectron spectroscopy (XPS), X-Ray Diffraction Analysis (XRD) and Raman spectroscopy methods. It was found that the chemical composition of ScAlSZ thin films was different from the chemical composition of the initial powder. Moreover, the Al concentration in thin films depends on the deposition rate, resulting in a lower concentration using a higher deposition rate. XPS analysis revealed that $\mathrm{ZrO}_{x}$, oxygen vacancies, high concentrations of $\mathrm{Al}_{2} \mathrm{O}_{3}$ and metallic $\mathrm{Al}$ exist in thin films and influence their structural properties. The crystallinity is higher when the concentration of $\mathrm{Al}$ is lower (higher deposition rate) and at higher substrate temperatures. Further, the amount of cubic phase is higher and the amount of tetragonal phase lower when using a higher deposition rate.
\end{abstract}

Keywords: co-doped zirconia; e-beam physical vapor deposition; thin films; ceramics; Raman spectroscopy; X-ray diffraction

\section{Introduction}

In the last few decades, materials based on zirconium oxide $\left(\mathrm{ZrO}_{2}\right)$ have been studied intensively due to their unique combination of thermal stability, strength, good electrochemical characteristics and low cost [1]. Pure zirconia exhibits three polymorphic types: Monoclinic, tetragonal and cubic. The monoclinic phase is retained up to around $1170{ }^{\circ} \mathrm{C}$. The structural changes to a tetragonal phase occur above this temperature. At a temperature of $2370^{\circ} \mathrm{C}$, the tetragonal phase transforms into a cubic fluorite structure, and melts at $2680 \pm 50^{\circ} \mathrm{C}[2,3]$. During the transformation from the monoclinic to the tetragonal phase, there is a volume change of around $4 \%$, which can induce defects in the material [4]. The mechanism for ionic conductivity is based on the oxygen vacancies formation, requiring high energy to remove oxygen atoms from the crystal lattice; therefore, pure zirconia is mainly an insulator. $\mathrm{Zr}^{4+}$ can be replaced by divalent or trivalent cations creating oxygen vacancies, and exhibits higher ionic conductivity [3]. Moreover, dopants can stabilize the cubic structure at room temperature. The most investigated are $\mathrm{Y}_{2} \mathrm{O}_{3}, \mathrm{Yb}_{2} \mathrm{O}_{3}, \mathrm{Sc}_{2} \mathrm{O}_{3}, \mathrm{Gd}_{2} \mathrm{O}_{3}, \mathrm{Dy}_{2} \mathrm{O}_{3}, \mathrm{Nd}_{2} \mathrm{O}_{3}, \mathrm{Sm}_{2} \mathrm{O}_{3}, \mathrm{CaO}$, and $\mathrm{MgO}$, etc. [4]. The stability of ceramic materials depends on the type and concentration of the dopant. $\mathrm{Sc}_{2} \mathrm{O}_{3}$ is considered as one of the most promising dopants. Scandia stabilized zirconia (ScSZ) is an interesting ceramic material that can be widely used in many applications, such as electrochemical oxygen 
gas sensors, oxygen pumps, catalytic support medium, etc. [1]. ScSZ has a unipolar conductivity, provided only by the oxygen ions in a wide range of temperatures and pressures $[5,6]$. The oxygen vacancy-induced ionic conductivity of zirconia-based ceramics is predominant up to sufficiently high temperatures $\left(1200^{\circ} \mathrm{C}\right)$ [2]. Consequently, ScSZ could compete with yttria-stabilized zirconia (YSZ) at intermediate temperatures $\left(600^{\circ} \mathrm{C}\right)$, where it has higher ionic conductivity than YSZ [7]. Sometimes, small concentrations (1-2 mol \%) of additional dopants (co-doping) are used to increase the concentration of scandia in $\mathrm{ZrO}_{2}$, maintaining cubic structure at the same time. Rare-earth elements or their oxides, such as $\mathrm{CeO}_{2}, \mathrm{Gd}_{2} \mathrm{O}_{3}, \mathrm{Sm}_{2} \mathrm{O}_{3}, \mathrm{Bi}_{2} \mathrm{O}_{3}, \mathrm{Yb}_{2} \mathrm{O}_{3}$, and $\mathrm{Al}_{2} \mathrm{O}_{3}$ [8-10], are good candidates to be co-dopants for ScSZ structures. For example, co-doping by $\mathrm{Al}_{2} \mathrm{O}_{3}$ can lead to a change in the structure, influencing mechanical and electrical properties [11-16]. However, the desired effect is obtained using only low concentrations of $\mathrm{Al}_{2} \mathrm{O}_{3}(<1 \mathrm{wt} . \%)$. The great majority of investigations are concentrated on the material pellets and powders. Al co-doped ScSZ thin films and their properties based on the phase transitions have not been studied enough. The properties of thin films are strongly related to the formation method and formation parameters. The e-beam physical vapor deposition method is one of the most suitable methods for forming ceramic layers. A high temperature is produced by the collision of the electrons and the material in the crucible. It can increase by over $3000^{\circ} \mathrm{C}$. The melting temperature for most of the metal oxides is lower. The deposition rate can be adjusted over a wide range using the e-beam evaporation technique, which is not possible to do using the magnetron sputtering technique for metal oxides. Thin films are dense and homogeneous. Moreover, the structure of thin films does not depend on the structure of the initial material because zirconia-based materials evaporate by partial dissociation. However, there are some disadvantages to this method. One of them is that materials with different melting temperatures evaporate at different rates. So, it is hard to deposit thin films with the desired composition if the material is multicomponent. Scandia and alumina stabilized zirconia (ScAlSZ) are not exceptions. Therefore, in our work, $\left(\mathrm{Sc}_{2} \mathrm{O}_{3}\right)_{0.06}\left(\mathrm{Al}_{2} \mathrm{O}_{3}\right)_{0.01}\left(\mathrm{ZrO}_{2}\right)_{0.93}(6 \mathrm{ScAlSZ})$ thin films were deposited using an e-beam physical deposition system by changing the deposition rate $(0.2-1.6 \mathrm{~nm} / \mathrm{s})$ and temperature $\left(300\right.$ and $\left.600{ }^{\circ} \mathrm{C}\right)$. After that, the chemical composition and structural properties were investigated. EDS and XPS were used for the determination of chemical composition. The structure analysis of zirconia materials is complicated due to its polymorphism. The peaks in the XRD patterns of crystalline phases (e.g., tetragonal and cubic) have similar positions and can overlap [17]. Therefore, XRD analysis was supplemented by Raman spectroscopy measurements. Raman spectroscopy is a very sensitive method and can give information about crystal structure, chemical composition and oxygen vacancies $[13,14]$. Moreover, there is plenty of literature describing different phases of $\mathrm{ZrO}_{2}$, which is helpful for detailed analysis of the structure: Monoclinic (m) [18-20], tetragonal (t) $[2,7,17-20]$, rhombohedral $(\beta)[2,18]$ and cubic $(c)[2,7,16,18]$.

\section{Materials and Methods}

Scandia alumina stabilized zirconia $\left(\mathrm{Sc}_{2} \mathrm{O}_{3}\right)_{0.06}\left(\mathrm{Al}_{2} \mathrm{O}_{3}\right)_{0.01}\left(\mathrm{ZrO}_{2}\right)_{0.93}$ (6ScAlSZ) micro powders (Nexceris, LLC, Fuelcellmaterials, Lewis Center, OH, USA) were used as evaporation materials. The particle size $\left(D_{50}\right)$ was $0.5-0.7 \mu \mathrm{m}$ and the specific surface area of the powders was $8-10 \mathrm{~m}^{2} \cdot \mathrm{g}^{-1}$. Thin films $(1.5 \mu \mathrm{m})$ of ScAlSZ were deposited by the e-beam physical vapor deposition system "Kurt J. Lesker EB-PVD 75" (Kurt J. Lesker Company, Pittsburg, PA, USA) on preheated Alloy 600 (Fe-Ni-Cr) substrates. The deposition rate was in the range of $0.2-1.6 \mathrm{~nm} / \mathrm{s}$ and the substrate temperatures were 300 and $600{ }^{\circ} \mathrm{C}$. The pressure during the deposition process was $9 \times 10^{-3} \mathrm{~Pa}$. The crystal structure of formed ceramic thin films was determined by X-ray diffraction (XRD, Bruker, Billerica, MA, USA) "Bruker D8 Discover" at $2 \theta$ angle in a $20^{\circ}-70^{\circ}$ range using $\mathrm{Cu} \mathrm{K} \alpha(\lambda=0.154059 \mathrm{~nm})$ radiation, $0.01^{\circ}$ steps and a Lynx eye PSD detector. The calculations of the crystallite size were done using the "TOPA4.1" software. The identification of diffraction peaks was performed using the EVA Search-Match software and PDF-2 database. The thicknesses of formed thin films were estimated using a profilometer (Ambios Technology XP-200, Keep Looking Ahead (KLA), San Jose, CA, USA). Raman spectroscopy measurements were carried out by inVia (Renishaw, Gloucestershire, UK) at room 
temperature. The $532 \mathrm{~nm}$ wavelength diode laser and $4 \mu \mathrm{m}$ diameter of the laser were used during the measurements. The laser spot was focused on a sample using a $50 \times$ objective (NA $=0.75$, Leica, Wetzlar, Germany). The integration time of signals was 15-30 s, which were accumulated 5 times and averaged. The diffraction gratings (2400 grooves $/ \mathrm{mm}$ ) provided spectral resolution of $1 \mathrm{~cm}^{-1}$. A Peltier cooled charge-coupled device (CCD) camera detector was used to record the data (Renishaw, Gloucestershire, UK) $(1024 \times 256$ pixels). The phase content of cubic, tetragonal and monoclinic phases in the ScAlSZ thin films were calculated using the relation between the most characteristic peaks of the Raman spectra [21]. Further, the factor $k[22,23]$ was used during the calculation of the phase ratio, where $k$ is the factor converting intensities between XRD and Raman spectra of the reference materials. The positions of Raman peaks were determined by fitting the data to the Lorentz line shape using a peak fit option in the OriginPro 2016 software. The phase ratio calculations were done according to the formula [21-23]:

$$
\vartheta_{c}=\frac{I_{c}}{k\left(I_{m}+I_{t}\right)+I_{c}}
$$

where $I_{c, m, t}$-peak intensities of cubic, monoclinic and tetragonal phases in Raman spectra, $k=0.97$.

The energy-dispersive X-ray spectroscope “BrukerXFlash QUAD 5040” (EDS, Bruker, Billerica, MA, USA)) was used to examine the elemental composition of formed ceramic thin films. Chemical analysis was estimated by the means of an X-ray photoelectron spectrometer (XPS, PHI Versaprobe 5000, ULVAC-PHI, Chigasaki, Kanagawa, Japan). The parameters were $\mathrm{Al} \mathrm{K} \alpha(1486.6 \mathrm{eV})$ radiation, $25 \mathrm{~W}$ power, $100 \mu \mathrm{m}$ beam size, $45^{\circ}$ measurement angle, $187.580 \mathrm{eV}$ pass energy, $1 \mathrm{eV}$ resolution for Survey Spectrum, and $0.1 \mathrm{eV}$ for detailed chemical analysis.

\section{Results}

X-ray diffraction patterns show that 6ScAlSZ powder has the following mixture of phases: Monoclinic (JCPDS No. 04-014-8566) and cubic (JCPDS No. 01-089-5485) of ScSZ, and rhombohedral (JCPDS No. 04-015-8608) of $\mathrm{Al}_{2} \mathrm{O}_{3}$ (Figure 1a). The monoclinic and cubic phases are predominant and show sharp peaks at (111), (200), (122), and (222), and some minor peaks at (011), (012), (002), (110), (211), (113), (024), (202), (116), and (300). The Raman spectra of 6ScAlSZ powder give similar information as XRD (Figure 1b). A comparison of the Raman spectra of initial powder and the literature data is in Figure 1b. Raman peaks were detected at 147, 178, 190, 221, 261, 332, 381, 418, 473, 536, 559, 620 , and $635 \mathrm{~cm}^{-1}$, and around $750-1000 \mathrm{~cm}^{-1}$ positions. They belong to the monoclinic $\left(\mathrm{m}-\mathrm{ZrO}{ }_{2}\right)$, cubic $\left(\mathrm{c}-\mathrm{ZrO}_{2}\right)$, rhombohedral $\left(\beta-\mathrm{Al}_{2} \mathrm{O}_{3}\right)$ and tetragonal $\left(\mathrm{t}-\mathrm{ZrO}_{2}\right)$ phases of $6 \mathrm{AlScSZ}$ powders. The former one was not found by doing XRD analysis. The Raman bands at 178, 190, 221, 332, 381, 473, and 559 were allocated to the Raman-active modes for the monoclinic phase of $\mathrm{ZrO}_{2}\left(\mathrm{~m}-\mathrm{ZrO}_{2}\right), \mathrm{A}_{\mathrm{g}}$ at $178-190 \mathrm{~cm}^{-1}$, $B_{1 \mathrm{~g}}$ at $221 \mathrm{~cm}^{-1}, B_{1 \mathrm{~g}}$ at $332 \mathrm{~cm}^{-1}, B_{g}$ at $381 \mathrm{~cm}^{-1}, A_{g}$ at $473 \mathrm{~cm}^{-1}$ and $A_{g}$ at $559 \mathrm{~cm}^{-1}$ [18-20,24,25]. The bands at 147, 261, and $635 \mathrm{~cm}^{-1}$ were assigned to the Raman-active modes for the tetragonal phase of $\mathrm{ZrO}_{2}\left(\mathrm{t}-\mathrm{ZrO}_{2}\right), \mathrm{B}_{1 \mathrm{~g}}$ at $147 \mathrm{~cm}^{-1}, \mathrm{E}_{\mathrm{g}}$ at $261 \mathrm{~cm}^{-1}$ and $\mathrm{A}_{1 \mathrm{~g}}$ at $635 \mathrm{~cm}^{-1}[10,20,26-28]$. The cubic zirconia (c- $\mathrm{ZrO}_{2}$ ) fluorite structure with the Fm3m space group and $\mathrm{F}_{2} \mathrm{~g}$ Raman mode symmetry should be centered between 605 and $630 \mathrm{~cm}^{-1}$, and the peak for $\mathrm{Al}_{2} \mathrm{O}_{3}$ is centered at $418 \mathrm{~cm}^{-1}[2,10,18,19,23,27]$.

The peaks at $261 \mathrm{~cm}^{-1}$ were assigned only for $\mathrm{t}-\mathrm{ZrO}_{2}$, and the peak at $178 \mathrm{~cm}^{-1}$ only for $\mathrm{m}-\mathrm{ZrO}$. The band at $473 \mathrm{~cm}^{-1}$ was stronger than the band at $635 \mathrm{~cm}^{-1}$ for the monoclinic phase, and the reverse is true for the tetragonal phase. The above-mentioned are the two main differences in the Raman spectra between the monoclinic phase and the tetragonal phase of zirconia. Furthermore, the bands between 473 and $635 \mathrm{~cm}^{-1}$, which are characteristic for the monoclinic phase, are not visible for the tetragonal phase [29]. Therefore, it is possible to conclude that the Raman spectra of the investigated initial powder of $6 \mathrm{ScAlSZ}$ show characteristic peaks of monoclinic $\left(\mathrm{m}-\mathrm{ZrO}_{2}\right)$, tetragonal $\left(\mathrm{t}-\mathrm{ZrO}_{2}\right)$ and cubic $\left(\mathrm{c}-\mathrm{ZrO}_{2}\right)$ zirconia.

The elemental composition of deposited ScAlSZ thin films fluctuates when using different deposition parameters according to the EDS measurements (Table 1). The mean concentrations of $\mathrm{O}_{2}$, $\mathrm{Al}$, Sc and $\mathrm{Zr}$ are $52.0 \pm 1.5,10.2 \pm 4.2,5.4 \pm 1.8$, and $32.6 \pm 2.5$ at. $\%$ respectively. Correlation between the 
deposition parameters and the concentrations of $\mathrm{O}_{2}, \mathrm{Sc}$, and $\mathrm{Zr}$ was not observed. The concentrations are scattered in the mentioned intervals.
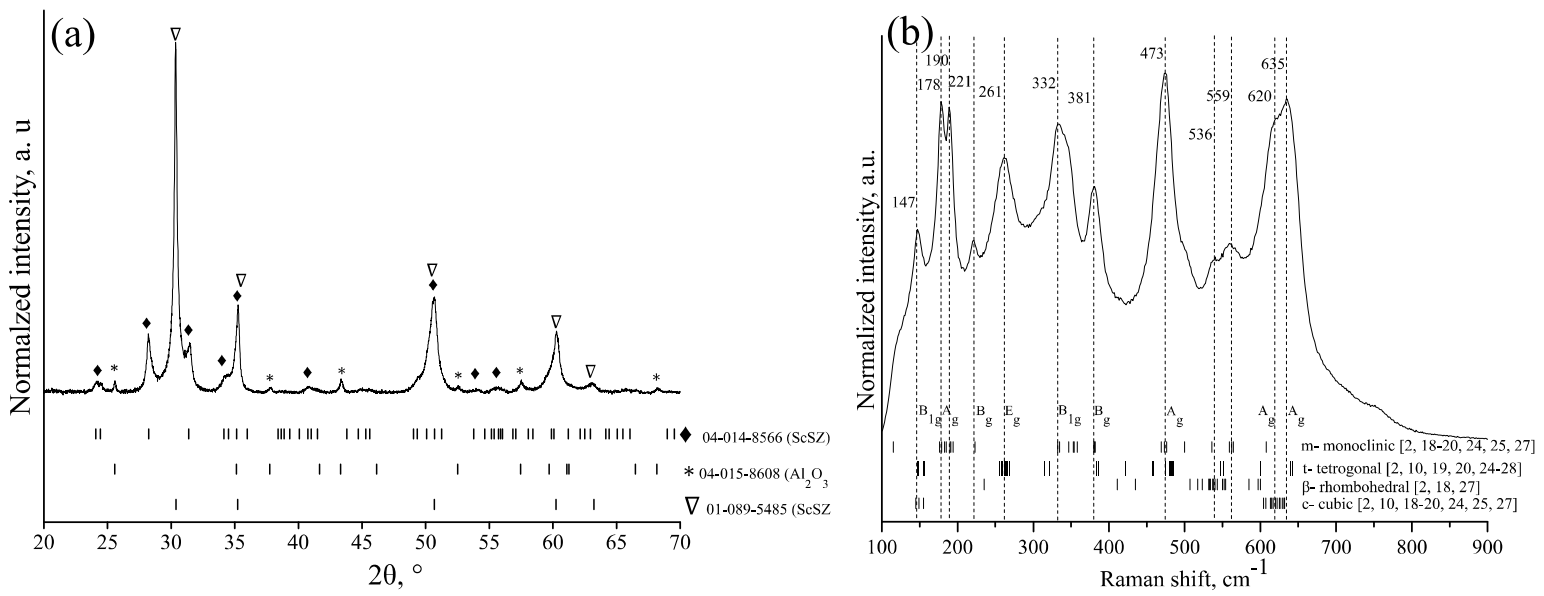

Figure 1. 6ScAlSZ powders: (a) X-ray diffraction (XRD) patterns and (b) Raman shifts.

Table 1. EDS analysis results of ScAlSZ thin films, $\left(v_{\mathrm{d}}\right.$-deposition rate, $T_{\mathrm{d}}$-substrate temperature during deposition, and $c$-atomic concentration).

\begin{tabular}{|c|c|c|c|c|c|c|c|c|}
\hline \multirow{2}{*}{$v_{\mathrm{d}}, \mathrm{nm} / \mathrm{s}$} & \multicolumn{4}{|c|}{$T_{\mathrm{d}}=300^{\circ} \mathrm{C}$} & \multicolumn{4}{|c|}{$T_{\mathrm{d}}=600^{\circ} \mathrm{C}$} \\
\hline & $c_{\mathrm{O}}$, at. $\%$ & $c_{\mathrm{Al}}$, at. $\%$ & $c_{\mathrm{Sc}}$, at. $\%$ & $c_{\mathrm{Zr}}$, at. $\%$ & $c_{\mathrm{O}}$, at. $\%$ & $c_{\mathrm{Al}}$, at. $\%$ & $c_{\mathrm{Sc},}$ at. $\%$ & $c_{\mathrm{Zr}}$, at. $\%$ \\
\hline 0.2 & 51.4 & 20.2 & 3.1 & 25.3 & 54.2 & 12.2 & 3.6 & 30.0 \\
\hline 0.4 & 49.5 & 12.4 & 3.6 & 34.5 & 49.8 & 12.5 & 3.4 & 34.3 \\
\hline 0.8 & 53.4 & 3.8 & 7.4 & 35.4 & 50.6 & 15.8 & 3.6 & 30.0 \\
\hline 1.2 & 51.5 & 6.4 & 8.7 & 33.5 & 53.6 & 8.0 & 6.7 & 31.8 \\
\hline 1.6 & 54.1 & 3.0 & 6.8 & 36.0 & 51.2 & 7.1 & 7.1 & 34.5 \\
\hline Powder & 52.0 & 12.6 & 3.9 & 32.5 & & & & \\
\hline
\end{tabular}

However, a relationship between $\mathrm{Al}$ and deposition rate was observed. The $\mathrm{Al}$ concentration changes non homogeneously with the increase in deposition rate and the substrate temperature (Figure 2). It changes from 20.2 to 3.0 at.\% for thin films deposited on $300{ }^{\circ} \mathrm{C}$ substrates (Figure 2a), and from 12.4 to 7.1 at.\% for thin films deposited on $600{ }^{\circ} \mathrm{C}$ substrates (Figure 2b). Furthermore, the mean value of $\mathrm{Al}$ concentration is slightly higher for thin films deposited at $600{ }^{\circ} \mathrm{C}\left(c_{\mathrm{Al} 300}=9.2\right.$ at. $\%$ and $c_{\mathrm{A} 1600}=11.1$ at.\%). With an increase in deposition rate, the temperature in the crucible increases, influencing the changes in the evaporation rate and vapor concentrations of different elements' atoms and atoms clusters. A decrease in $\mathrm{Al}$ concentration appears due to the different melting temperatures of $\mathrm{Al}_{2} \mathrm{O}_{3}\left(2072{ }^{\circ} \mathrm{C}\right), \mathrm{Sc}_{2} \mathrm{O}_{3}\left(2485^{\circ} \mathrm{C}\right)$ and $\mathrm{ZrO}_{2}\left(2715^{\circ} \mathrm{C}\right) . \mathrm{Al}_{2} \mathrm{O}_{3}$ evaporates faster than $\mathrm{Sc}_{2} \mathrm{O}_{3}$ and $\mathrm{ZrO}_{2}$. Moreover, the process of thin-film $(\sim 1500 \mathrm{~nm})$ formation takes longer at low deposition rates in comparison to higher deposition rates. So, a smaller amount of Al evaporates using a higher deposition rate for the same thickness of thin film.

The metallic $\mathrm{Al}$ or its compound phases in ScAlSZ thin films could form due to high $\mathrm{Al}$ concentration that exceed the solubility limit ( 7 at.\%) [30]. Therefore, the chemical composition of ScAlSZ thin films was investigated additionally using the XPS method. The surface of ScAlSZ consists of Sc, Zr, $\mathrm{Al}$, and $\mathrm{C}$ compounds, and $\mathrm{OH}$ groups (Figure $3 \mathrm{a}$ ). Detailed information on those compounds was obtained after analysis of the $\mathrm{O} 1 s, \mathrm{Zr} 3 d, \mathrm{Al} 2 p$ and $\mathrm{Sc} 2 p$ regions (Figure $3 \mathrm{~b}-\mathrm{e}$ ). The peak positions were compared with the literature, and it was found that $\mathrm{ZrO}_{x}$ suboxide $\left(3 d_{5 / 2}-181.96 \mathrm{eV}, 3 d_{3 / 2}-184.36 \mathrm{eV}\right.$ and $\mathrm{O} 1 s-530.05 \mathrm{eV})$, oxygen vacancies $(\mathrm{O} 1 s-531.40 \mathrm{eV}), \mathrm{Sc}_{2} \mathrm{O}_{3}\left(2 p_{3 / 2}-401.85 \mathrm{eV}, 2 p_{1 / 2}-406.40 \mathrm{eV}\right.$ and $\mathrm{O} 1 s-529.65 \mathrm{eV}), \mathrm{Al}_{2} \mathrm{O}_{3}(2 p-73.69 \mathrm{eV}$ and $\mathrm{O} 1 s-530.85 \mathrm{eV})$, metallic $\mathrm{Al}(2 p-72.90 \mathrm{eV}), \mathrm{AlO}(\mathrm{OH})$ $(2 p-74.82 \mathrm{eV}), \mathrm{OH}(\mathrm{O} 1 \mathrm{~s}-532.70 \mathrm{eV}), \mathrm{C}-\mathrm{O}(\mathrm{O} 1 \mathrm{~s}-533.17 \mathrm{eV})$ and $\mathrm{C}=\mathrm{O}(\mathrm{O} 1 \mathrm{~s}-532.03 \mathrm{eV})$ exist on the 
surface of ScAlSZ thin films [31-35]. Similar positions of binding energies were found for ScSZ by Xue et al. in [28]. $\mathrm{OH}$ and $\mathrm{CO}$ groups were formed naturally in an ambient environment, and do not influence bulk properties. Therefore, they will be excluded from further discussion. The existence of $\mathrm{ZrO}_{x}$ and oxygen vacancies, high concentrations of $\mathrm{Al}_{2} \mathrm{O}_{3}$ and metallic $\mathrm{Al}$ can affect the structural properties of ScAlSZ thin films $[36,37]$.
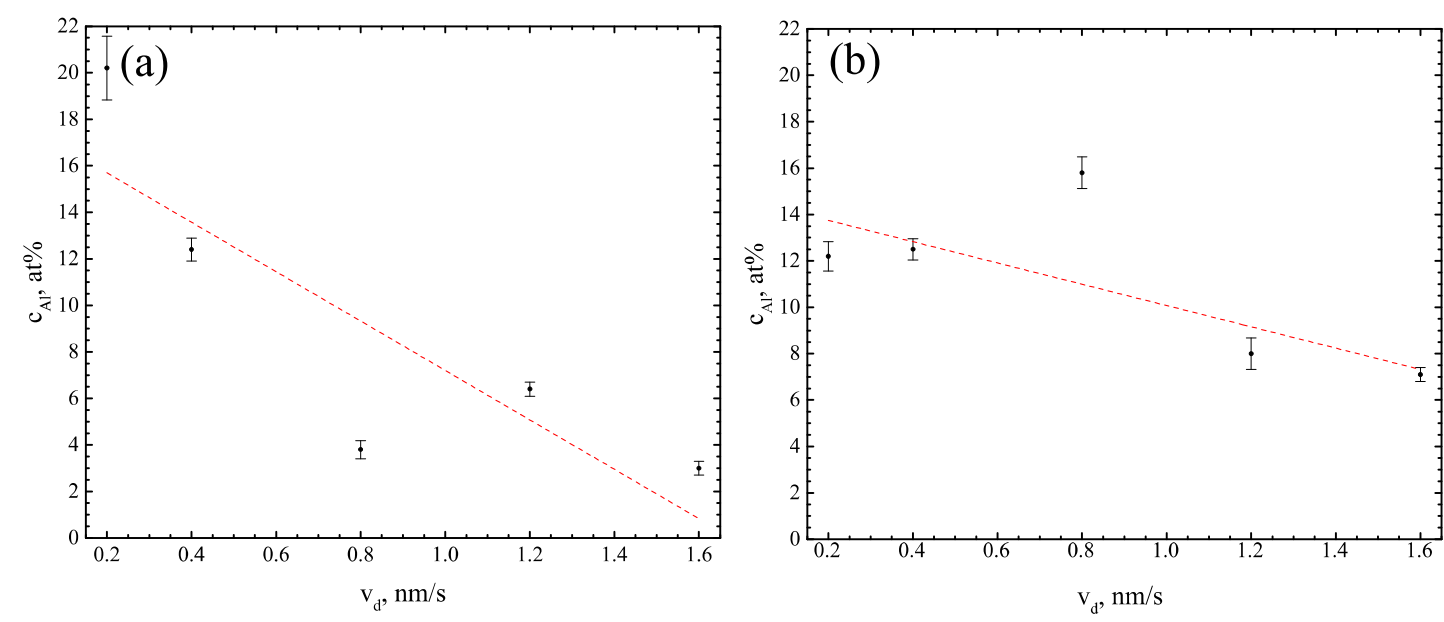

Figure 2. Aluminum concentration in $6 \mathrm{ScAlSZ}$ thin films: (a) $T_{\mathrm{d}}=300{ }^{\circ} \mathrm{C}$ and $(\mathbf{b}) T_{\mathrm{d}}=600{ }^{\circ} \mathrm{C}$.
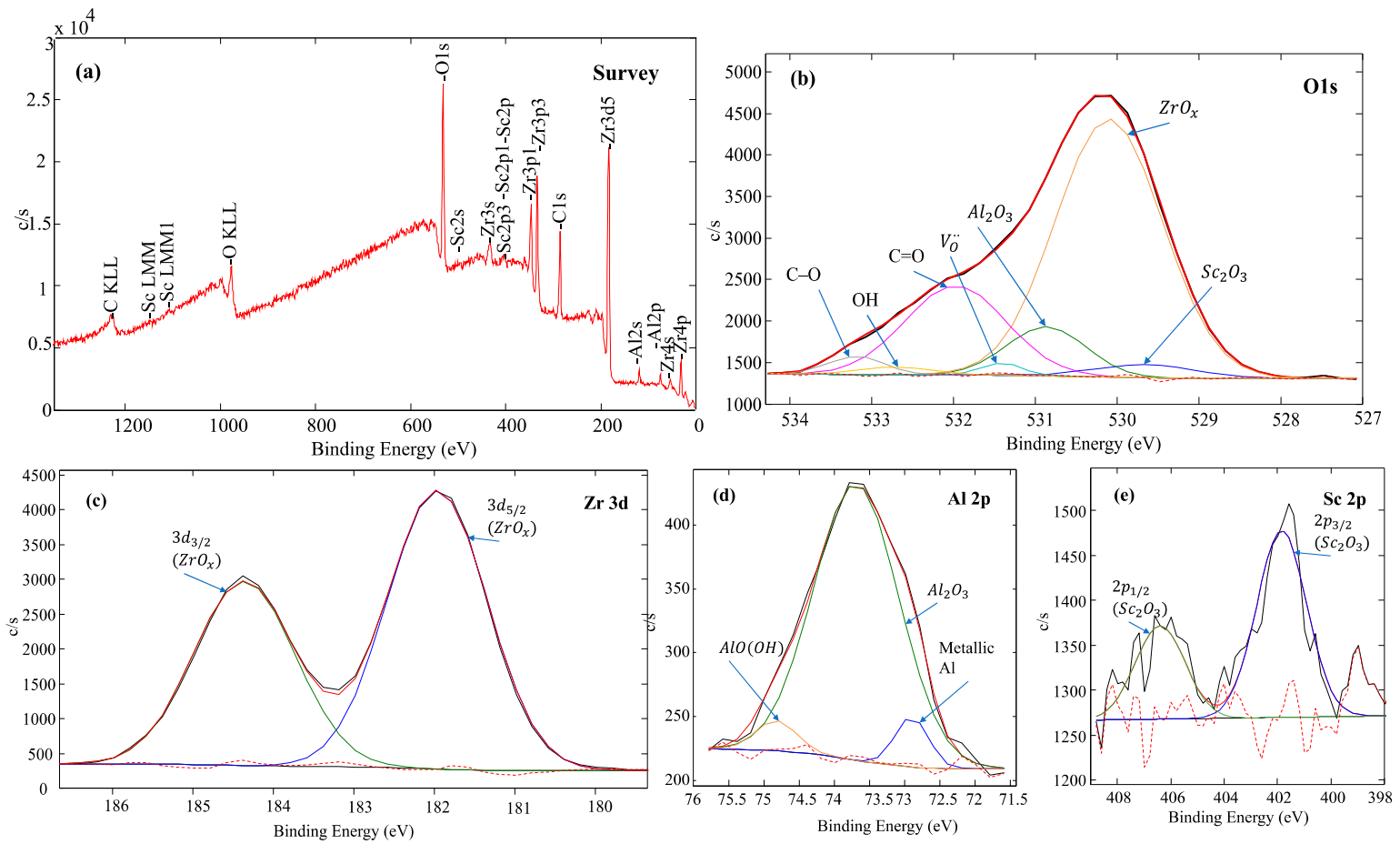

Figure 3. XPS spectra of $6 \mathrm{ScAlSZ}$ thin films $\left(v_{\mathrm{d}}=0.2 \mathrm{~nm} / \mathrm{s}, \mathrm{T}_{\mathrm{d}}=300^{\circ} \mathrm{C}\right)$ : (a) survey, (b) $\mathrm{Zr} \mathrm{O} 1 \mathrm{~s},(\mathbf{c}) \mathrm{Zr} 3 d$, (d) $\operatorname{Al} 2 p,(\mathbf{e}) \mathrm{Sc} 2 p$.

The XRD measurement proves the previous assumption (Figure 4). ScAlSZ thin films deposited on $300{ }^{\circ} \mathrm{C}$ substrates are amorphous at lower deposition rates $(0.2-0.4 \mathrm{~nm} / \mathrm{s})$ and polycrystalline $(17.5-19.7 \mathrm{~nm})$ at higher deposition rates $(0.8-1.6 \mathrm{~nm} / \mathrm{s})$. According to the search-match procedure, the XRD patterns of thin films have peaks indicating the cubic phase of scandia stabilized zirconia (JCPSD No. 01-089-5485), the tetragonal phase of aluminum stabilized zirconia (JCPSD No. 00-053-0549) and the tetragonal phase of zirconia (JCPSD No. 01-084-9828). We did not observe peaks that could 
belong to $\mathrm{Al}_{2} \mathrm{O}_{3}$. However, it is hard to tell which phase and compound certainly are in the ScAlSZ thin films due to the low number of overlapped and shifted peaks. XRD analysis revealed that the crystallinity is higher using a higher deposition rate, i.e., the peak intensity is higher and the crystallites are larger using a higher deposition rate. The crystallite size is $11.3-18.9 \mathrm{~nm}$ using a $0.2-1.6 \mathrm{~nm} / \mathrm{s}$ deposition rate, respectively. The crystallinity of thin films correlates with the concentration of $\mathrm{Al}$ and substrate temperature. It increases with decreasing $\mathrm{Al}$ concentration and increasing substrate temperature. The amorphous phases of $\mathrm{Al}$ or $\mathrm{Al}_{2} \mathrm{O}_{3}$ possibly formed in the grain boundaries of ScAlSZ crystallites, and act as impurities. Therefore, grain growth was suppressed at high $\mathrm{Al}$ concentrations. The crystallinity decreases by increasing the $\mathrm{Al}$ concentration in $\mathrm{ZrO}_{2}$ thin films deposited using an atomic layer deposition technique [38]. Moreover, it was found that amorphous thin films grow then the concentration of $\mathrm{Al}$ is $9.7 \%$ [39]. On the other hand, Ishii. T. states that an increasing $\mathrm{Al}_{2} \mathrm{O}_{3}$ concentration may result from the destruction of the oxygen vacancy ordering of the low temperature rhombohedral phase. A cubic phase was obtained when the $\mathrm{Al}$ concentration was $0.5 \%$ [9]. Furthermore, the grain size and phase could be influenced by the variations in oxygen content in the formed thin films [40].
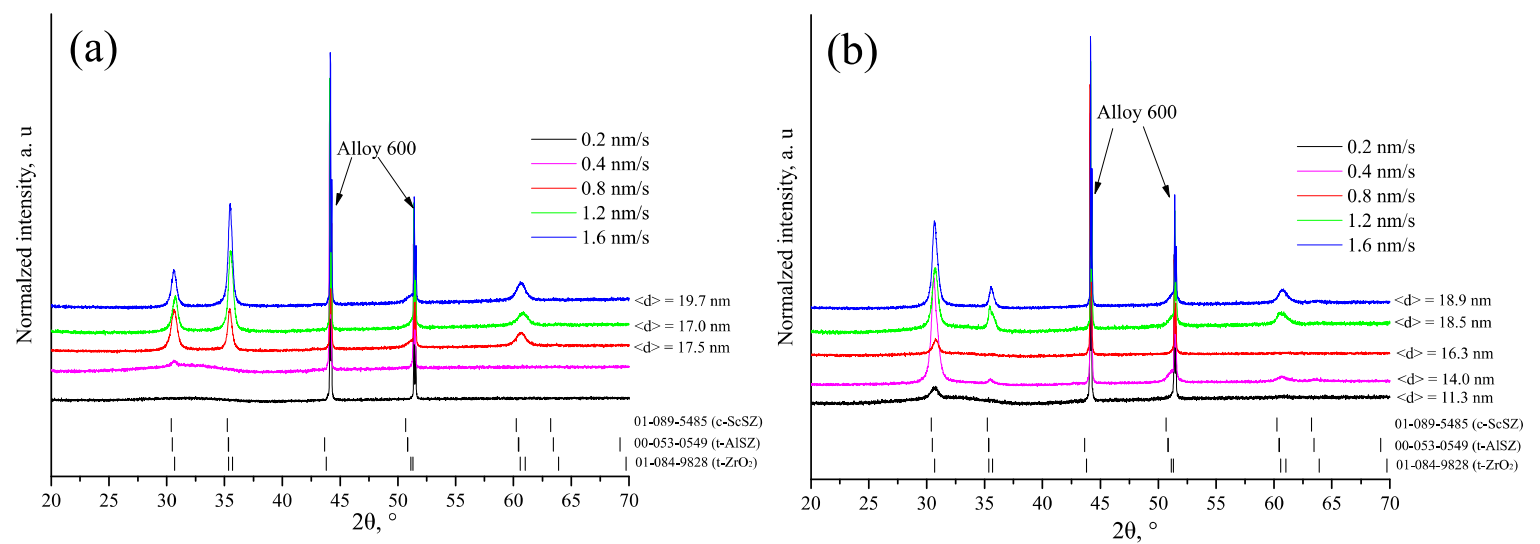

Figure 4. XRD patterns (measured at room temperature) of 6ScAlSZ thin films deposited on Alloy 600 substrates using (a) $300{ }^{\circ} \mathrm{C}$ and (b) $600{ }^{\circ} \mathrm{C}$ substrate temperatures and different deposition rates from 0.2 to $1.6 \mathrm{~nm} / \mathrm{s}$.

To fully identify the structure of the ScAlSZ thin films, Raman measurements were made. The Raman spectra of ScAlSZ thin films have many overlapping peaks, indicating polymorphism. After careful analysis, it was determined that the peaks belong to monoclinic $\left(\mathrm{m}-\mathrm{ZrO}_{2}\right)$, tetragonal $\left(\mathrm{t}-\mathrm{ZrO}_{2}\right)$, rhombohedral $\left(\mathrm{Rh}-\mathrm{ZrO}_{2}\right)$ and cubic $\left(\mathrm{c}-\mathrm{ZrO}_{2}\right)$ phases (Figure 5). Raman spectra peaks are detected around 150, 200, 264, 460, 540, 627, and $638 \mathrm{~cm}^{-1}$, and peaks between 770 and $900 \mathrm{~cm}^{-1}$ could be attributed to the Raman active lattice phonons and can be assigned to monoclinic and tetragonal phases $[24,25]$. The Raman shift in the peak position can be explained by the presence of structural heterogeneity in the material. Peak positions greater than $800 \mathrm{~cm}^{-1}$ belong to the second-order active Raman modes [41]. The broad peaks expressed between 149 and $277 \mathrm{~cm}^{-1}$ consist of several peaks, indicating different $\mathrm{ZrO}_{2}$ phases. Peaks around $198 \mathrm{Ag}_{\mathrm{g}}$ match the peaks of the monoclinic $\mathrm{ZrO}_{2}$ phase [18-20]. The characteristic bands for the tetragonal $\mathrm{ZrO}_{2}$ phase are expressed by six Raman active modes $\left(\mathrm{A}_{1 \mathrm{~g}}+2 \mathrm{~B}_{1 \mathrm{~g}}+3 \mathrm{E}_{\mathrm{g}}\right)$. Raman peaks detected from 149 to $153 \mathrm{~cm}^{-1}$ and around $638 \mathrm{~cm}^{-1}$ match the $\mathrm{A}_{1 \mathrm{~g}}$ mode of $\mathrm{t}-\mathrm{ZrO}_{2}[10,20,26-28]$. In Figure 5, the broad peaks expressed between 626 and $630 \mathrm{~cm}^{-1}$ indicate the cubic (c) phase. Raman peak shifts, for the cubic phase, to the higher wavenumbers might appear due to oxygen sublattice disorder induced by the doping and co-doping of $\mathrm{Sc}_{2} \mathrm{O}_{3}$ and $\mathrm{Al}_{2} \mathrm{O}_{3}[10,18,19,27]$. Moreover, there can be several reasons for wavenumber shifting, including the change of atomic distances or lattice contraction or expansion, for example. So, AlScSZ thin films are polymorphic and consist of monoclinic $\left(\mathrm{m}-\mathrm{ZrO}_{2}\right)$, tetragonal $\left(\mathrm{t}-\mathrm{ZrO}_{2}\right)$, rhombohedral $\left(\beta-\mathrm{ZrO}_{2}\right)$ and cubic $\left(\mathrm{c}-\mathrm{ZrO}_{2}\right)$ phases. The Raman spectra of the ScAlSZ thin films deposited at $0.2 \mathrm{~nm} / \mathrm{s}$ and $0.4 \mathrm{~nm} / \mathrm{s}$ at $300{ }^{\circ} \mathrm{C}$, and $0.2,0.4$, and $0.8 \mathrm{~nm} / \mathrm{s}$ at $600{ }^{\circ} \mathrm{C}$, prove the existence of the cubic phase 
since cubic symmetry must be expressed by a broad band around $620-630 \mathrm{~cm}^{-1}$, which is not observed in the Raman spectra of those thin films. Peaks around $687 \mathrm{~cm}^{-1}$ can be interpreted as anomalous luminescence bands.
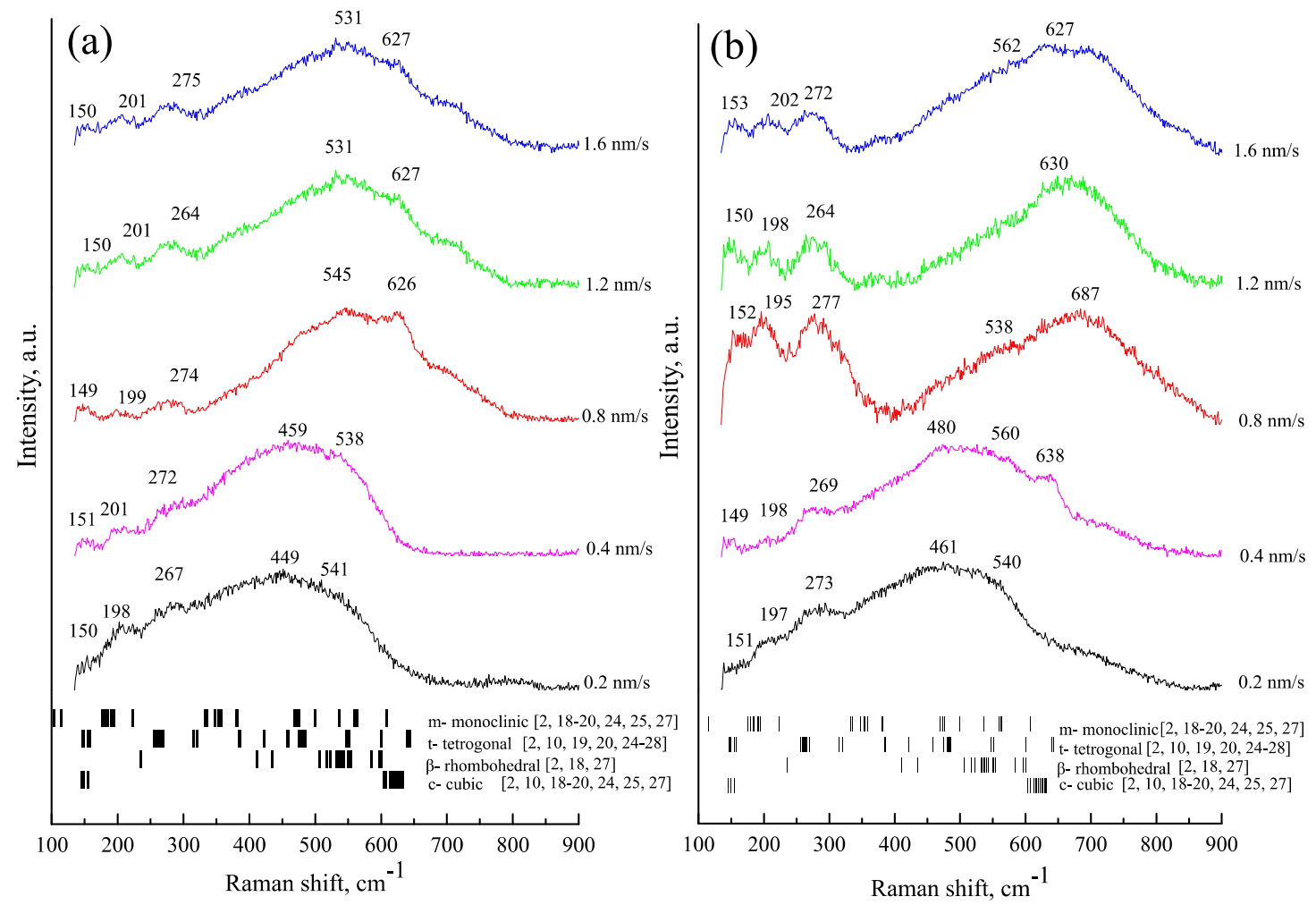

Figure 5. Raman spectra of 6ScAlSZ thin films deposited on Alloy 600 substrates using (a) $300{ }^{\circ} \mathrm{C}$ and (b) $600{ }^{\circ} \mathrm{C}$ substrate temperature and different deposition rates from 0.2 to $1.6 \mathrm{~nm} / \mathrm{s}$.

The additional modes that should not appear for the cubic fluorite structure could be explained by the consistent violation of the selection rules, which directly depend on oxygen vacancies that can be reached by the substitution of $\mathrm{Zr}^{4+}$ by Sc $\mathrm{c}^{3+}[42,43]$.

The ratios of the cubic phase to the monoclinic, tetragonal phases are from $53 \%$ to $59 \%$ for $6 \mathrm{ScAlSZ}$, and are generally around 55\% (Table 2). By increasing the depositing rate, the amount of cubic phase increases. The obtained results demonstrate that at the 0.2 and $0.4 \mathrm{~nm} / \mathrm{s}$ deposition rates, the cubic phase is not detected. However, the presence of the broad bands, which are presented in Figure 4 and are indicative of local disorder, could be a result of the non-stoichiometric phase of $\mathrm{ZrO}_{2}$ and a poorly crystallized $\mathrm{Zr}^{4+}$ and $\mathrm{Sc}^{3+}$ structure. To conclude, thin films at small deposition rates are of a mixed phase $\left(\mathrm{m}-\mathrm{ZrO}_{2}\right),\left(\mathrm{t}-\mathrm{ZrO}{ }_{2}\right)$.

Table 2. The ratio of cubic, tetragonal and monoclinic phases in the ScAlSZ thin films.

\begin{tabular}{ccccccc}
\hline & \multicolumn{5}{c}{ Substrate Temperature $\left({ }^{\circ} \mathbf{C}\right)$} \\
\cline { 2 - 7 } Deposition Rate (nm/s) & $\mathbf{3 0 0}$ & $\mathbf{6 0 0}$ & $\mathbf{3 0 0}$ & $\mathbf{6 0 0}$ & $\mathbf{3 0 0}$ & $\mathbf{6 0 0}$ \\
\cline { 2 - 7 } & \multicolumn{2}{c}{ Monoclinic } & Tetragonal + Rhombohedral & \multicolumn{2}{c}{ Cubic } \\
\hline 0.2 & $35 \%$ & $28 \%$ & $65 \%$ & $72 \%$ & $0 \%$ & $0 \%$ \\
0.4 & $19 \%$ & $12 \%$ & $81 \%$ & $88 \%$ & $0 \%$ & $0 \%$ \\
0.8 & $6 \%$ & $54 \%$ & $41 \%$ & $46 \%$ & $53 \%$ & $0 \%$ \\
1.2 & $19 \%$ & $20 \%$ & $26 \%$ & $26 \%$ & $55 \%$ & $53 \%$ \\
1.6 & $19 \%$ & $18 \%$ & $26 \%$ & $23 \%$ & $55 \%$ & $59 \%$ \\
\hline
\end{tabular}




\section{Conclusions}

Thin films of scandia alumina stabilized zirconia were formed using the e-beam physical vapor deposition method. Pellets for the deposition process were prepared from the powders of $\left(\mathrm{Sc}_{2} \mathrm{O}_{3}\right)_{0.06}$ $\left(\mathrm{Al}_{2} \mathrm{O}_{3}\right)_{0.01}\left(\mathrm{ZrO}_{2}\right)_{0.93}$. The crystalline structure of powders was polymorphic. Monoclinic, cubic and rhombohedral phases were identified using XRD and Raman methods. Deposited thin films had a different structure and chemical composition in comparison to powders of 6ScAlSZ. The concentrations of $\mathrm{O}_{2}, \mathrm{Al}, \mathrm{Sc}$ and $\mathrm{Zr}$ were $52.0 \pm 1.5,10.2 \pm 4.2,5.4 \pm 1.8$, and $32.6 \pm 2.5$ at.\% respectively. It was found that the $\mathrm{Al}$ concentration in thin films was related to the deposition parameters, i.e., deposition rate and substrate temperature. The concentration of $\mathrm{Al}$ was lower using a higher deposition rate, and slightly higher using a higher substrate temperature. The XPS measurements revealed that the surface of thin films consists of Sc, $\mathrm{Zr}, \mathrm{Al}$ and $\mathrm{C}$ compounds, oxygen vacancies and $\mathrm{OH}$ groups. The existence of $\mathrm{ZrO}_{x}$ and oxygen vacancies, a high concentration of $\mathrm{Al}_{2} \mathrm{O}_{3}$ and metallic $\mathrm{Al}$ affected the structural properties of thin films. The crystallinity of the thin films was made greater using a higher deposition rate and deposition temperature. In other words, the crystallinity was directly related to the aluminum concentration and the substrate temperature. It was also found that thin films are polymorphic. Raman analysis revealed that thin films consist of monoclinic, tetragonal, cubic, and small amounts of rhombohedral phases. Moreover, the amount of cubic phase was higher and the amount of tetragonal phase was lower using a higher deposition rate. Hence, a high concentration of $\mathrm{Al}$ in the thin films suppresses the formation of the cubic phase. The most optimal conditions for obtaining thin films with the most stabilized cubic structure were obtained at high substrate temperatures and high deposition rates.

Author Contributions: Conceptualization, G.L. and N.K.; methodology, M.S., K.B., and G.L.; formal analysis, N.K., M.S., and K.B.; e-beam deposition D.V.; Raman spectroscopy, N.K.; XPS and EDS analysis, M.S.; XRD analysis M.S. and D.V.; writing-original draft preparation, M.S. and N.K.; writing-review and editing, N.K., K.B., M.S., and G.L.; visualization, N.K. and M.S.; supervision, G.L.; funding acquisition, G.L. All authors have read and agreed to the published version of the manuscript.

Funding: This research was funded by the European Regional Development Fund according to the supported activity “Research Projects Implemented by World-class Researcher Groups” under Measure No. 01.2.2-LMT-K-718.

Conflicts of Interest: The authors declare no conflict of interest.

\section{References}

1. Walter, E.J.; Lewis, S.P.; Rappe, A.M. First principles study of carbon monoxide adsorption on zirconia-supported copper. Surf. Sci. 2001, 495, 44-50. [CrossRef]

2. Sriubas, M.; Kainbayev, N.; Virbukas, D.; Bočkute, K.; Rutkuniene, Ž.; Laukaitis, G. Structure and conductivity studies of scandia and alumina doped zirconia thin films. Coatings 2019, 9, 317. [CrossRef]

3. Zavodinsky, V.G. The mechanism of ionic conductivity in stabilized cubic zirconia. Phys. Solid State 2004, 46, 453-457. [CrossRef]

4. Badwal, S.P.S.; Ciacchi, F.T. Oxygen-ion conducting electrolyte materials for solid oxide fuel cells. Ionics 2000, 6,1-21. [CrossRef]

5. Lee, D.S.; Kim, W.S.; Choi, S.H.; Kim, J.; Lee, H.W.; Lee, J.H. Characterization of $\mathrm{ZrO}_{2}$ co-doped with $\mathrm{Sc}_{2} \mathrm{O}_{3}$ and $\mathrm{CeO}_{2}$ electrolyte for the application of intermediate temperature SOFCs. Solid State Ion. 2005, 176, 33-39. [CrossRef]

6. Liu, Y.; Lao, L.E. Structural and electrical properties of ZnO-doped $8 \mathrm{~mol} \%$ yttria-stabilized zirconia. Solid State Ion. 2006, 177, 159-163. [CrossRef]

7. Mahato, N.; Gupta, A.; Balani, K. Doped zirconia and ceria-based electrolytes for solid oxide fuel cells: A review. Nanomater. Energy 2012, 1, 27-45. [CrossRef]

8. Sarat, S.; Sammes, N.; Smirnova, A. Bismuth oxide doped scandia-stabilized zirconia electrolyte for the intermediate temperature solid oxide fuel cells. J. Power Sources 2006, 160, 892-896. [CrossRef]

9. Ishii, T. Structural phase transition and ionic conductivity in $0.88 \mathrm{ZrO}_{2}(0.12-x) \mathrm{Sc}_{2} \mathrm{O}_{3} x \mathrm{Al}_{2} \mathrm{O}_{3}$. Solid State Ion. 1995, 78, 333-338. [CrossRef]

10. Wang, Z.; Cheng, M.; Bi, Z.; Dong, Y.; Zhang, H.; Zhang, J.; Feng, Z.; Li, C. Structure and impedance of $\mathrm{ZrO}_{2}$ doped with $\mathrm{Sc}_{2} \mathrm{O}_{3}$ and $\mathrm{CeO}_{2}$. Mater. Lett. 2005, 59, 2579-2582. [CrossRef] 
11. Yamamoto, O.; Arati, Y.; Takeda, Y.; Imanishi, N.; Mizutani, Y.; Kawai, M.; Nakamura, Y. Electrical conductivity of stabilized zirconia with ytterbia and scandia. Solid State Ion. 1995, 79, 137-142. [CrossRef]

12. Omar, S.; Belda, A.; Escardino, A.; Bonanos, N. Ionic conductivity ageing investigation of 1Ce10ScSZ in different partial pressures of oxygen. Solid State Ion. 2011, 184, 2-5. [CrossRef]

13. Hirano, M.; Oda, T.; Ukai, K.; Mizutani, Y. Effect of $\mathrm{Bi}_{2} \mathrm{O}_{3}$ additives in Sc stabilized zirconia electrolyte on a stability of crystal phase and electrolyte properties. Solid State Ion. 2003, 158, 215-223. [CrossRef]

14. Belous, A.G.; V'Yunov, O.I.; Gunes, V.; Bohnke, O. Ionic and electronic conductivities of yttria- and scandia-stabilized zirconia. Inorg. Mater. 2014, 50, 1235-1241. [CrossRef]

15. Guo, C.X.; Wang, J.X.; He, C.R.; Wang, W.G. Effect of alumina on the properties of ceria and scandia co-doped zirconia for electrolyte-supported SOFC. Ceram. Int. 2013, 39, 9575-9582. [CrossRef]

16. Agarkov, D.A.; Borik, M.A.; Bredikhin, S.I.; Burmistrov, I.N.; Eliseeva, G.M.; Kolotygin, V.A.; Kulebyakin, A.V.; Kuritsyna, I.E.; Lomonova, E.E.; Milovich, F.O.; et al. Structure and transport properties of zirconia crystals co-doped by scandia, ceria and yttria. J. Mater. 2019, 5, 273-279. [CrossRef]

17. Zhang, F.; Reveron, H.; Spies, B.C.; van Meerbeek, B.; Chevalier, J. Trade-off between fracture resistance and translucency of zirconia and lithium-disilicate glass ceramics for monolithic restorations. Acta Biomater. 2019, 91, 24-34. [CrossRef] [PubMed]

18. Dasari, H.P.; Ahn, J.S.; Ahn, K.; Park, S.Y.; Hong, J.; Kim, H.; Yoon, K.J.; Son, J.W.; Lee, H.W.; Lee, J.H. Synthesis sintering and conductivity behavior of ceria-doped Scandia-stabilized zirconia. Solid State Ion. 2014, 263, 103-109. [CrossRef]

19. Hirata, T.; Asari, E.; Kitajima, M. Infrared and raman spectroscopic studies of $\mathrm{ZrO}_{2}$ polymorphs doped with $\mathrm{Y}_{2} \mathrm{O}_{3}$ or $\mathrm{CeO}_{2}$. J. Solid State Chem. 1994, 110, 201-207. [CrossRef]

20. Li, L.; Wang, W. Synthesis and characterization of monoclinic $\mathrm{ZrO}_{2}$ nanorods by a novel and simple precursor thermal decomposition approach. Solid State Commun. 2003, 127, 639-643. [CrossRef]

21. Huy, L.D.; Laffez, P.; Daniel, P.; Jouanneaux, A.; Khoi, N.T.; Siméone, D. Structure and phase component of $\mathrm{ZrO}_{2}$ thin films studied by Raman spectroscopy and X-ray diffraction. Mater. Sci. Eng. B Solid-State Mater. Adv. Technol. 2003, 104, 163-168. [CrossRef]

22. Porozova, S.E.; Smetkin, A.A.; Solnyshkov, I.V. Surface composition and structure of highly porous materials based zirconia stabilized with yttria. Russ. J. Non-Ferrous Met. 2017, 58, 664-669. [CrossRef]

23. Clarke, D.R.; Adar, F. Measurement of the crystallographically transformed zone produced by fracture in ceramics containing tetragonal zirconia. J. Am. Ceram. Soc. 1982, 65, 284-288. [CrossRef]

24. Basahel, S.N.; Ali, T.T.; Mokhtar, M.; Narasimharao, K. Influence of crystal structure of nanosized $\mathrm{ZrO}_{2}$ on photocatalytic degradation of methyl orange. Nanoscale Res. Lett. 2015, 10, 73. [CrossRef]

25. Gazzoli, D.; Mattei, G.; Valigi, M. Raman and X-ray investigations of the incorporation of $\mathrm{Ca}^{2+}$ and $\mathrm{Cd}^{2+}$ in the $\mathrm{ZrO}_{2}$ structure. J. Raman Spectrosc. 2007, 38, 824-831. [CrossRef]

26. Nomura, K.; Mizutani, Y.; Kawai, M.; Nakamura, Y.; Yamamoto, O. Aging and raman scattering study of scandia and yttria doped zirconia. Solid State Ion. 2000, 132, 235-239. [CrossRef]

27. Kumar, A.; Jaiswal, A.; Sanbui, M.; Omar, S. Scandia stabilized zirconia-ceria solid electrolyte $(x \operatorname{Sc} 1 \mathrm{CeSZ}, 5<x<11)$ for IT-SOFCs: Structure and conductivity studies. Scr. Mater. 2016, 121, 10-13. [CrossRef]

28. Xue, Q.; Huang, X.; Zhang, H.; Xu, H.; Zhang, J.; Wang, L. Synthesis and characterization of high ionic conductivity ScSZ core/shell nanocomposites. J. Rare Earths 2017, 35, 567-573. [CrossRef]

29. Li, M.; Feng, Z.; Ying, P.; Xin, Q.; Li, C. Phase transformation in the surface region of zirconia and doped zirconia detected by UV Raman spectroscopy. Phys. Chem. Chem. Phys. 2003, 5, 5326-5332. [CrossRef]

30. Lyamina, G.; Ilela, A.; Khasanov, O.; Petyukevich, M.; Vaitulevich, E. Synthesis of $\mathrm{Al}_{2} \mathrm{O}_{3}-\mathrm{ZrO}_{2}$ powders from differently concentrated suspensions with a spray drying technique. In AIP Conference Proceedings; American Institute of Physics Inc.: College Park, MD, USA, 2016; Volume 1772, p. 020011. [CrossRef]

31. Morant, C.; Sanz, J.M.; Galán, L.; Soriano, L.; Rueda, F. An XPS study of the interaction of oxygen with zirconium. Surf. Sci. 1989, 218, 331-345. [CrossRef]

32. Milanov, A.P.; Xu, K.; Cwik, S.; Parala, H.; de los Arcos, T.; Becker, H.W.; Rogalla, D.; Cross, R.; Paul, S.; Devi, A. $\mathrm{Sc}_{2} \mathrm{O}_{3}, \mathrm{Er}_{2} \mathrm{O}_{3}$, and $\mathrm{Y}_{2} \mathrm{O}_{3}$ thin films by MOCVD from volatile guanidinate class of rare-earth precursors. Dalt. Trans. 2012, 41, 13936-13947. [CrossRef]

33. Ganguly, A.; Sharma, S.; Papakonstantinou, P.; Hamilton, J. Probing the thermal deoxygenation of graphene oxide using high-resolution in situ X-ray-based spectroscopies. J. Phys. Chem. C. 2011, 115, 17009-17019. [CrossRef] 
34. Raja, J.; Nguyen, C.P.T.; Lee, C.; Balaji, N.; Chatterjee, S.; Jang, K.; Kim, H.; Yi, J. Improved data retention of InSnZnO nonvolatile memory by $\mathrm{H}_{2} \mathrm{O}_{2}$ treated $\mathrm{Al}_{2} \mathrm{O}_{3}$ tunneling layer: A cost-effective method. IEEE Electron Device Lett. 2016, 37, 1272-1275. [CrossRef]

35. Corsi, J.S.; Fu, J.; Wang, Z.; Lee, T.; Ng, A.K.; Detsi, E. Hierarchical bulk nanoporous aluminum for on-site generation of hydrogen by hydrolysis in pure water and combustion of solid fuels. ACS Sustain. Chem. Eng. 2019, 7, 11194-11204. [CrossRef]

36. Srdić, V.V.; Winterer, M. Aluminum-doped zirconia nanopowders: Chemical vapor synthesis and structural analysis by rietveld refinement of X-ray diffraction data. Chem. Mater. 2003, 15, 2668-2674. [CrossRef]

37. Dahl, G.T.; Döring, S.; Krekeler, T.; Janssen, R.; Ritter, M.; Weller, H.; Vossmeyer, T. Alumina-doped zirconia submicro-particles: Synthesis, thermal stability, and microstructural characterization. Materials 2019, 12, 2856. [CrossRef]

38. Yoo, Y.W.; Jeon, W.; Lee, W.; An, C.H.; Kim, S.K.; Hwang, C.S. Structure and electrical properties of Al-doped $\mathrm{HfO}_{2}$ and $\mathrm{ZrO}_{2}$ films grown via atomic layer deposition on Mo electrodes. ACS Appl. Mater. Interfaces 2014, 6, 22474-22482. [CrossRef]

39. Spiga, S.; Rao, R.; Lamagna, L.; Wiemer, C.; Congedo, G.; Lamperti, A.; Molle, A.; Fanciulli, M.; Palma, F.; Irrera, F. Structural and electrical properties of atomic layer deposited $\mathrm{Al}$-doped $\mathrm{ZrO}_{2}$ films and of the interface with TaN electrode. J. Appl. Phys. 2012, 112, 014107. [CrossRef]

40. Gorji, N.E. Oxygen incorporation into CdS/CdTe thin film solar cells. Opt. Quantum Electron 2015, 47, $2445-2453$. [CrossRef]

41. Siu, G.G.; Stokes, M.J.; Liu, Y. Variation of fundamental and higher-order raman spectra of (formula presented) nanograins with annealing temperature. Phys. Rev. B Condens. Matter Mater. Phys. 1999, 59, 3173-3179. [CrossRef]

42. Marrocchelli, D.; Madden, P.A.; Norberg, S.T.; Hull, S. Structural disorder in doped zirconias, part II: Vacancy ordering effects and the conductivity maximum. Chem. Mater. 2011, 23, 1365-1373. [CrossRef]

43. Kosacki, I.; Suzuki, T.; Anderson, H.U.; Colomban, P. Raman scattering and lattice defects in nanocrystalline $\mathrm{CeO}_{2}$ thin films. Solid State Ion. 2002, 149, 99-105. [CrossRef]

(C) 2020 by the authors. Licensee MDPI, Basel, Switzerland. This article is an open access article distributed under the terms and conditions of the Creative Commons Attribution (CC BY) license (http://creativecommons.org/licenses/by/4.0/). 